\title{
Double Gantzer's Muscles by Four Muscle Bellies and Its Clinical Significance: A Case Report
}

\author{
Si-Wook Lee ${ }^{1}$, Jae-Ho Lee ${ }^{2}$, Hyunsu Lee ${ }^{2}$ \\ ${ }^{1}$ Department of Orthopedic Surgery, School of Medicine, Keimyung University \\ ${ }^{2}$ Department of Anatomy, School of Medicine, Keimyung University \\ (Received 3 March 2017, revised 16 March 2017, accepted 22 March 2017)
}

\begin{abstract}
The Gantzer's muscle (GM) is an additional muscle in the forearm as the accessory head of the flexor pollicis longus (FPL) and accessory head of the flexor digitorum profundus (FDP). We reported a rare case of double GM formed by four muscle bellies. From the dorsal part of flexor digitorum superficialis, small four bellies formed two muscles merging to FDP and FPL, as GMs. These accessory heads of FDP and FPL crossed the ulnar artery and the median nerve, respectively. These additional muscles in the forearm flexor compartment are rare and its clinical and embryological significances should be considered.
\end{abstract}

Keywords : Gantzer's muscle, Flexor digitorum profundus, Flexor pollicis longus, Variation

\section{Introduction}

Among the anatomical variations of the muscles in the forearm, the Gantzer's muscle (GM) have been described its prevalence and morphological variation in the previous studies [1-4]. This additional muscle was found as the accessory head of flexor pollicis longus (FPL) and accessory head of flexor digitorum profundus (FDP). Although the prevalence of GM was described variously, it is persistently found in about $50 \%$ of Asian $[3,4]$. The various origin of the GM has been shown from medial humeral epicondyle, coronoid process or dual origin from medial epicondyle and coronoid process [1-5]. Its insertion was constantly reported to attach to the ulnar border of the FPL and to the wrist level tendon of the FDP, respectively.

The author(s) agree to abide by the good publication practice guideline for medical journals.

The author(s) declare that there are no conflicts of interest.

Correspondence to : Hyunsu Lee (Department of Anatomy, School of Medicine, Keimyung University)

E-mail : neuroana@dsmc.or.kr
Although controversial, the presence of this muscle confers to be an important source of compression of the nerves with potential clinical significance, such as anterior interosseous nerve (AIN) syndrome or pronator teres syndrome [2-6]. Variable anatomical and topographical relationships between the GM and the median nerve or AIN have been studied, however, the variation pattern of the GM was also extremely different $[7,8]$. Here, we reported a rare case with double GM in Korean cadaver for the first time and discussed its clinical significance.

\section{Case Report}

Variation in the muscular structure was observed in the right upper limb of the cadaver of a 81-years-old Korean female during educational dissection. The dissection was performed through a midline incision on the forearm, and skin, subcutaneous tissues, and fascia were exposed. The flexor digitorum superficialis muscle (FDS) was identi-

(C) 2017 Korean Association of Physical Anthropologists

This is an Open Access article distributed under the terms of the Creative Commons Attribution Non-Commercial License (http://creativecommons.org/ licenses/by-nc/3.0) which permits unrestricted non-commercial use, distribution, and reproduction in any medium, provided the original work is properly cited.

ISSN 2287-626X (Online) · ISSN 1225-150X (Print) 


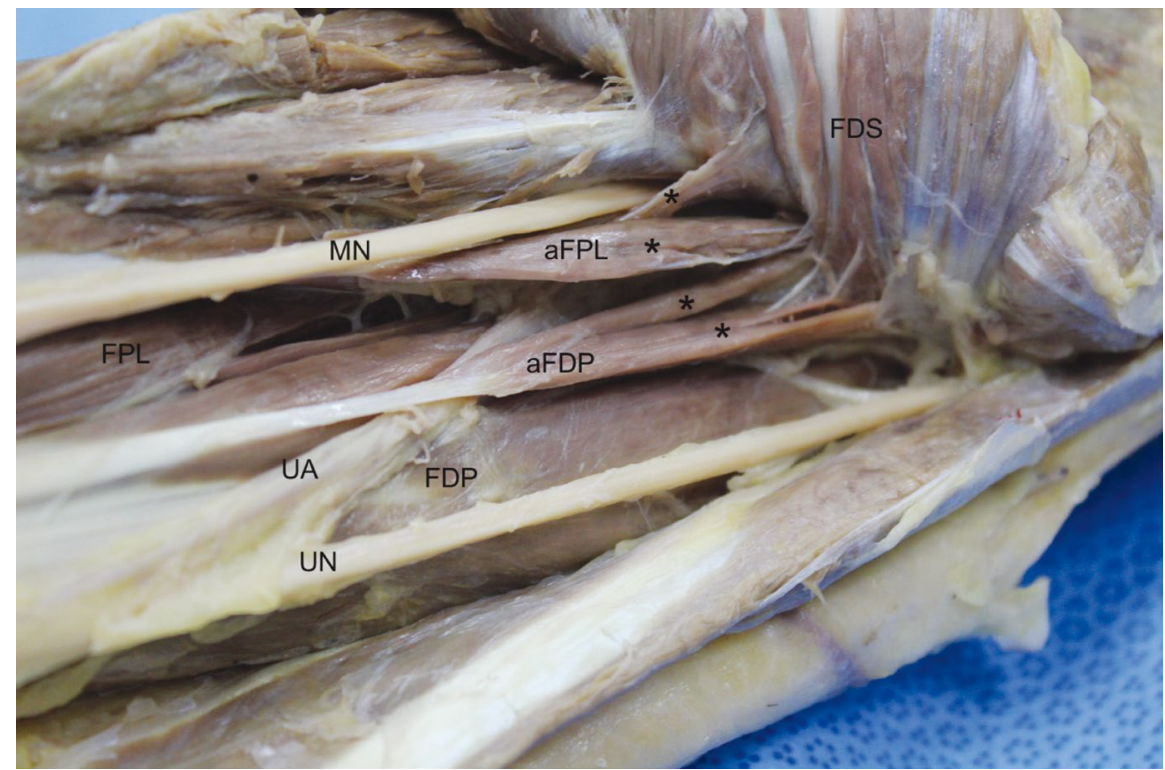

Fig. 1. Under flexor digitorum superficialis (FDS), four muscle bellies (*) formed two Gantzer's muscles, as accessory heads of the flexor digitorum profundus (aFDP) and flexor pollcis longus (aFPL). FDP, flexor digitorum profundus; FPL, flexor pollcis longus; MN, median nerve; UA, ulnar artery; UN, ulnar nerve.

fied and then it was reflected to examine its deep layer. There were two additional muscles, originating from the proximal part of FDS (Fig. 1). One of them, medial one joined by two small bellies crossed the ulnar artery. And its tendon part merged into FDP as accessory head of FDP (aFDP). The lateral one also formed by two small bellies continued deep to the median nerve and merged into the FPL as accessory head of FPL (aFPL). These accessory muscles were innervated by AIN. The length of aFDP and aFPL were $8.2 \mathrm{~cm}$ and $7.7 \mathrm{~cm}$, respectively. There was no evidence of any pathological involvement of the GM and nervous structures.

\section{Discussion}

Previous studies reported the incidence of the GM was found to be $45 \%$ to $66.7 \%$ and it was slightly more common bilaterally in cadavers with a prevalence of $52.1 \%$, than unilaterally, which had a prevalence of $47.9 \%[2,4,8]$. Roy J [8] also reported a prevalence rate of $50.5 \%$ in North America, $44.9 \%$ in Asia and $37.0 \%$ in Europe through meta-analysis. Although there is reports that aFPL showed a high prevalence rate of $89.9 \%$ in blacks descent [3] and a low prevalence of $33 \%$ in European Caucasians, Roy $\mathrm{J}$
[8] did not conclude any significant differences of aFPL prevalence between the races because most studies did not report the races of the population. Although there are reports that a prevalence of aFPL When present the GM mostly originated from the medial epicondyle of the humerus or the under surface of FDS muscle, as in the present case [8]. It has been reported that the insertion sites of the GM were the FDP or the FPL, and the more common form of the GM was aFPL [2,8-10].

Two or three GMs have been reported infrequently. Nayak SR [11] reported triple GMs, as accessory heads of FDS, FDP and FPL. Eid N and Otsuki Y [12] also demonstrated double GMs with different anatomical relation to the median and AIN. Unlike the previous case with two aFPL reported by Eid N and Otsuki Y [12], present case showed two GMs, as aFDP and aFPL. The prevalence of the GM was common, however, coexistence of aFDP and aFPL was rare. Interestingly, these two muscles were formed by four muscular bellies. And these additional muscles have a relationship to neurovascular structures. aFDP crossed superficial to the ulnar artery and aFPL continued deep to the median nerve. Because aFPL is a more common type, studies have been reported on neurological effects of it on MN or AIN [6,12]. Though the clinical effect of this anatomical arrangement has not been iden- 
tified obviously, the presence of multiple GMs may result in restricted movement of forearm flexors and subsequent pain in lower forearm [5,6]. On the other hand, GM may be used in local transfers in peripheral neuropathy $[11,12]$. Therefore, awareness of this variation may be useful servant for many clinicians and be important to prevent complications during or after surgical interventions and diagnostic procedures.

In this report, we showed double GMs having four bellies and its association with neurovascular structures for a first time. The presence of additional muscles may be originated form the incomplete cleavage of the forearm flexor muscles during development as the deep layer of the flexor muscle mass gives rise to the FDS, FDP and FPL [1]. Based on the embryological implications of the GM, we recently examined the topology of the GM and its adjunct neurovascular structures and found that the diverging point of ulnar artery was more distal in the presence of the GM [13]. In addition to its effect on arterial variation, the effect of the GM on neurovascular structures should be studied by larger cases of cadavers further.

\section{REFERENCES}

1. Al-Qattan M. Gantzer's muscle: An anatomical study of the accessory head of the flexor pollicis longus muscle. J Hand Surg Br. 1996; 21:269-70.

2. El Domiaty MA, Zoair MM, Sheta AA. The prevalence of accessory heads of the flexor pollicis longus and the flexor digitorum profundus muscles in Egyptians and their relations to median and anterior interosseous nerves. Folia Morphol. 2008; 67:63-71.

3. Kara A, Elvan O, Yildiz S, Ozturk H. Accessory head of flexor pollicis longus muscle in fetuses and adult cadavers and its relation to anterior interosseous nerve. Clin Anat. 2012; 25:601-8.

4. Oh CS, Chung IH, Koh KS. Anatomical study of the accessory head of the flexor pollicis longus and the anterior interosseous nerve in Asians. Clin Anat. 2000; 13:434-8.

5. Shirali S, Hanson M, Branovacki G, Gonzalez M. The flexor pollicis longus and its relation to the anterior and posterior interosseous nerves. J Hand Surg Br. 1998; 23:170-2.

6. Tabib W, Aboufarah F, Asselineau A. Compression of the anterior interosseous nerve by Gantzer's muscle. Chir Main. 2001; 20:241-6.

7. Riveros A, Olave E, Sousa-Rodrigues C. Anatomical study of the accessory head of the flexor pollicis longus and its relation to the anterior interosseous nerve in Brazilian individuals. Int J Morphol. 2015; 33:31-5.

8. Roy J, Henry BM, Pękala PA, Vikse J, Ramakrishnan PK, Walocha JA, et al. The prevalence and anatomical characteristics of the accessory head of the flexor pollicis longus muscle: a meta-analysis. PeerJ. 2015; 3:e1255.

9. Pai MM, Nayak SR, Krishnamurthy A, Vadgaonkar R, Prabhu LV, Ranade AV, et al. The accessory heads of flexor pollicis longus and flexor digitorum profundus: Incidence and morphology. Clin Anat. 2008; 21:252-8.

10. Jones M, Abrahams PH, Sanudo JR, Campillo M. Incidence and morphology of accessory heads of flexor pollicis longus and flexor digitorum profundus (Gantzer's muscles). J Anat. 1997; 191:451-5.

11. Nayak SR, Sharma S, Dasgupta H, Bhattacharya K. Presence of triple Gantzer's muscle - a rare anatomical variation. NUJHS. 2013; 3:69-71.

12. Eid N, Otsuki Y. A case of double Gantzer's muscle and its possible role in nerve entrapment. Clin Anat. 2009; 22:8812.

13. Yang K, Jung SJ, Lee H, Choi IJ, Lee JH. Topographical relations between the Gantzer's muscle and neurovascular structures. Surg Radiol Anat. 2017. DOI:10.1007/s00276016-1803-x 


\section{네 개의 근육덩이로 이루어진 Gantzer근육 변이와 임상적 의의: 증례 보고}

이시욱 ${ }^{1}$, 이재호 $^{2}$, 이현수 $^{2}$

${ }^{1}$ 계명대학교 의과대학 정형외과학교실, ${ }^{2}$ 계명대학교 의과대학 해부학교실

간추림 : Gantzer근육은 아래팔에 있는 부수적인 근육으로, 긴엄지굽힘근과 깊은손가락굽힘근의 덧갈래 형태로 발 견된다. 본 증례에서는 근육덩이 네 개로 이루어진 Gantzer근육 쌍을 보고하고자 한다. 본 증례의 Gantzer근육은 얕 은손가락굽힘근의 등쪽에서부터 네 개의 근육덩이가 시작되어 두 개의 근육 쌍으로 합쳐지며 각각 긴엄지굽힘근과 깊은손가락굽힘근으로 닿는 양상이었다. 긴엄지굽힘근과 깊은손가락굽힘근의 덧갈래근육은 각각 정중신경과 자동 맥을 교차했다. 이러한 형태의 아래팔근육변이는 드문 경우로서, 관련된 임상적, 발생학적 의의를 요약하였다.

찾아보기 낱말 : Gantzer근육, 깊은손가락굽힘근, 긴엄지굽힘근, 변이 